\title{
Vision-Based Leadership At Southeast Asia's Leading Service Enterprise: Etic Or Emic?
}

Sooksan Kantabutra, Mahidol University, Bangkok, Thailand

\begin{abstract}
Corporate leaders are exhorted to espouse vision, but little is known about how vision is realized by leaders at different levels in Southeast Asian service sector. The present study tests relationships between perceived vision communication, motivation of employees and organizational alignment among supervisors, and satisfaction of their immediate subordinates at a headquarters branch of one of Southeast Asia's leading hotel and resort groups. Motivation of employees directly predicts improvements in employee satisfaction. Aligning organizational systems is negatively correlated to perceived motivating behavior among hotel supervisors. Surprisingly, vision communication has no significant relationship with employee satisfaction. Future research directions and managerial implications are discussed.
\end{abstract}

Keywords: Vision-Based Leadership; Vision Communication; Organizational Alignment

\section{INTRODUCTION}

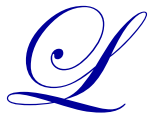

eadership researchers are divided into two groups when it comes to considering the universality of new leadership theories, such as the prevailing vision-based leadership theories. While the etic proponents argue that new leadership theories are universal, the emic ones argue it to be culture specific. Even though the first group dominates the second with many theoretical and empirical supports (Hetland and Sandal, 2003), the studies which take the etic approach are questioned by researchers about the legitimacy of the belief of the universality of leadership. Empirically, many cross-cultural studies have also supported that leadership is a culture bound concept and culturally unique or at least that considerably distinctive leadership constructs certainly exist (Jayakody, 2008).

In Southeast Asia, a few reported studies have attempted to culturally validate the new leadership theories. Simply limited to East Asia (Boehnke, Bontis, Distefano and Distefano, 2003; Dorfman and Howell, 1997) or Israel (Popper and Druyan, 2001; Popper and Sleman, 2001) and Iran (Javidan and Carl, 2004), many of the cross-cultural studies that claim to be conducted in "Asia" or "The East" do not apparently appear to cover Southeast Asia. Yet the results have been used to deliberately generalize new leadership theories to the entire Asia. This is a premature generalization because Southeast Asian countries are indeed significantly different from East Asian countries and the Middle East in many respects, i.e. level of economic development, religion and cultural values (Gupta, Surie, Javidan and Chhokar, 2002), despite the fact that Southeast Asia belongs to the so-called Asian cultures. Therefore, the generalization of the new theories to Southeast Asia is highly questionable, indicating an urgent need to validate the new leadership theories in Southeast Asia.

Given an urgent need to validate the new leadership theories in Southeast Asia, the present study contributes to enhancing our understanding about the extent to which Vision-based leadership can be used to explain leadership phenomenon in Thailand. Derived from a literature review, a structural model, relating vision realization factors to employee satisfaction, is developed and tested in a luxury hotel in Bangkok to determine their effectiveness. Findings and managerial implications are discussed. 


\section{VISION REALIZATION}

Moving toward the new leadership theories, the emphasis on leadership thoughts has since the 1980s shifted from traits and leader behaviours to the need for leaders to articulate vision to their employees, particularly those in organizations undergoing major change (e.g. Bass, 1990; Conger, 1991; Conger and Kanungo, 1987; Lucey, Bateman and Hines, 2005). More critically, researchers (e.g. Avery, 2005; Hamel and Prahalad, 1989) have asserted that an organization with a well-articulated vision can achieve sustained competitive advantage over those organizations lacking such a vision. Many leadership scholars have even regarded vision as fundamental to leadership, strategy implementation, and change (Avery, 2004; Collins and Porras, 1994; Doz and Prahalad, 1987; Humphreys, 2004; Hunt, 1991; Kotter, 1990; Robbins and Duncan, 1988; Sashkin, 1988). Vision indeed works in various ways by providing a connection between present and future, serving to best energize employees toward the future, giving meaning to people's lives and work, and setting a standard of excellence in an organization (Avery, 2004; Daft and Lengel, 1998; Nanus, 1992). A guiding star to draw everyone along the same path toward the future, vision can also garner commitment from employees (Daft, 2005).

Despite its clear importance, vision is still not defined in a universally agreed upon manner (Kantabutra, 2010a). It is frequently confused with, or even deliberately combined with, mission, goals, strategy, values and organizational philosophy (Kantabutra, 2008a; Kantabutra and Avery, 2002). Therefore, a vision is operationally defined in the present study as a mental model that each leader defines, given that it is the leader's actual mental model that guides his/her choices and actions (Kantabutra, 2009).

Vision alone is not sufficient to lead successfully. It contributes only 10 per cent of the success, and implementation the rest (Jick, 2001). Kantabutra (2005) endorses Jick by asserting that educational leaders are required to, among other things, communicate their visions, empower and motivate teachers to bring about desirable performance outcomes. Once an effective vision is developed, the vision must be communicated to employees who then must be motivated and empowered to carry out the vision (Avolio, 1999; Kotter, 2001; McShane and Von Glinow, 2000). It must be noted at this point that much of the leadership literature has focused on 'distant' leaders, who are several levels away from employees, rather than on immediate leaders. As leaders need to inspire and motivate employees in ways that go beyond economic exchange, 'close' leaders can have a more powerful and positive impact on follower satisfaction (Aarons, 2006; Alimo-Metcalfe and Alban-Metcalfe, 2006), indicating a focus for the present study.

In a cross-cultural context, the evidence concerning the 'fit' of contemporary leadership demonstrates mixed results. Many studies support a culturally specific leadership approach (Jayakody, 2008), while others support visionary leadership as a universal approach with some small divergence cross cultures. A classic study conducted across 62 cultures, including Thai culture, found that several attributes reflecting vision-based leadership are universally endorsed as contributing to outstanding leadership (Den Hartog, House, Hanges, and RuizQuintanilla, 1999). Specifically in Europe, Brodbeck et al. (2000) reported that leadership models differ systematically with cultural values held by employees in ten different European regions. However, the visionary leadership was one of the traits that were perceived as facilitating outstanding leadership in all European regions, except for France. In Asia, visionary leadership was perceived to be the fifth most effective leadership attribute from a study in India (Mukherjee, 2004). Singh and Krishnan (2002) undertook a study in North India and found considerably lower reliability in all leadership areas, except 'vision'. Visionary leadership is also reported as one of highly desired leadership attributes according to research in Qatar and Kuwait (Kabasakal and Dastmalchian, 2001). Similarly, studies in Turkey (Pasa, Kabasakal, and Bodur, 2001) and Iran (Dastmalchian, Javidan, and Alam, 2001) identify visionary leadership behavior as part of effective leader profiles. In Thailand, limited studies on visionary leadership have been reported. Among a few exceptions, Kantabutra (2008b) found that Thai retail store managers who acted as a role model, built employee self-confidence, created challenges for employees, and rewarded staff who acted consistently with their visions are directly predictive of enhanced staff satisfaction. With such mixed results, researchers need to explore if visionary leadership is indeed a universal approach.

The present study therefore fills in the gap in the literature by exploring relationships between vision realization factors and job satisfaction of immediate employees at all levels of a luxury hotel in Bangkok, Thailand, given that leadership should not be confined to only the top level (Joyce, 2004; Currie, Boyett, and Suhomlinova, 2005). Based on the literature, each vision realization theme is discussed in detail below. 


\section{Vision Communication}

Visionary leaders communicate their visions to promote changes and broaden support among their employees. Vision communication has long been regarded in the leadership literature as a key to successful implementation of a vision (e.g. Avery, 2004; Kantabutra, 2010a). Clearly, leaders must communicate their visions in ways that reach out to organization members, gripping them at heart and making them want to get involved in carrying out the visions (Sashkin, 1985). Concurrently, they must focus attention, communicate personally, demonstrate trustworthiness, display respect, and take risks. A leader needs to speak about the vision so that employees can grasp the message. Employees can then use the vision to guide daily operations. When employees share a direction, they are not confused and do not get lost on their way. They know what they are supposed to be doing within their roles and responsibilities to achieve the vision. When they are satisfied, productivity often increases. Vision and its effective communication lead to its whole-hearted adoption by the employees (Baum, Locke and Kirkpatrick, 1998).

Vision communication has been extensively studied as determinants of the success of the entrepreneur as a leader (Baum and Locke, 2004; Baum et al., 1998; Tarabishy, Solomon, Fernald and Sashkin, 2005). In Thai retail stores, vision communication is an indirect predictor of improved staff satisfaction (Kantabutra, 2008b). Moreover, store managers who are perceived by their staff to, among other things, communicate their visions frequently and passionately predict improvements in staff satisfaction (Kantabutra, 2011). Similarly, vision communication was indirectly predictive of improved staff satisfaction in Australian retail stores (Kantabutra and Avery, 2007). More specifically, store managers who communicated their visions to their staff through written and technology-mediated channels were indirectly associated with enhanced staff satisfaction.

Although many ways of communicating vision exist, vision continues to be communicated predominantly in the traditional form of brief, highly elevated written vision statements (Larwood, Falbe, Kriger and Miesling, 1995). Vision communication in this present study is operationally defined as the extent to which a supervisor is perceived by his/her subordinates to communicate his/her vision through (1) spoken, (2) written and (3) technologymediated channels.

\section{Empowerment of Employees}

Empowerment emphasizes delegation and passing power from higher organizational levels to lower ones (Carson and King, 2005), giving employees the independence to make decisions and commitments instead of just suggesting them (Forrester, 2000). Employees must also be given the ability to exercise power. Power and empowerment interact as a complex multi-dimensional concept (Hardy and Leibia-O'Sullivan, 1998) that influences decision outcomes and controls process access. Although some employees are more empowered than others, they should not be viewed as empowered or not empowered (Spreitzer, 1995). Visionary leaders empower their people to enable them to act consistently with the new vision and to assist in sustaining their commitment to it (Conger and Kanungo, 1987; Cowley and Domb, 1997; Nanus, 1992; Robbins and Duncan, 1987; Sashkin, 1988). Empowerment is indeed the genuine downward distribution/relinquishment of power and control over circumstances, i.e., control over context and relationship dynamics change (Kantabutra, 2008b). Relatively, where senior managers are visibly seen to voluntarily let go of some of their power and control, and where employees in fact value the increased power and control they are given, empowerment is seen to be effective. Empowerment frees energies that may have otherwise been held by internal resistance, political and power struggles.

Empirically, empowerment of staff was directly predictive of enhanced staff satisfaction in Australian retail stores (Kantabutra and Avery, 2007). Store managers who delegated work to employees, provided resources and support services to employees, and encouraged employees to make more decisions, were directly associated with improved staff satisfaction. In Thai retail stores, empowerment of staff was an indirect predictor of improved staff satisfaction (Kantabutra, 2008b), lending support to the Australian study. In the UK local government research, empowering, delegating, and developing subordinates' potential were found to be significant predictors of satisfying leadership style (Alban-Metcalfe and Alimo-Metcalfe, 2000). 
Accordingly, empowerment is defined in the present study as the extent to which a supervisor is perceived by his/her subordinates to (1) delegate work to subordinates, (2) provide resources and support services to subordinates, and (3) encourage subordinates to make more decisions regarding daily operations.

\section{Motivation of Employees}

Obviously, motivation plays a critical role in the visionary leadership process, since leaders cannot alone attain their visions. Visionary leaders motivate their employees to implement their visions, particularly in times of difficulty (e.g. Awamleh and Gardner, 1999). They motivate and communicate, which requires social skills, trust, a focus on results, and other conditions for a highly spirited organization (Maciariello, 2006). Motivation comes from people decisions, job design, high expectations for performance, and sound decisions on compensation and rewards (Maciariello, 2006). Visionary leaders also increase people's expectations about the relationship between their efforts and accomplishments, particularly when employees meet the leader's high expectations. In doing so, employees' perceived self-efficacy, a strong source of motivation (Bandura, 1986), is enhanced.

Additionally, numerous studies (e.g. Bass, 1990; Kotter, 1988) found that effective leaders were consistently viewed as credible and outstandingly trustworthy. Consistently, Kantabutra (2009)'s vision theory asserts that vision as a leadership tool must be stable; unstable vision leads to low morale among employees. A leader's integrity is, therefore, critical because employees recognize very soon the extent to which a manager really stands behind the vision, not only within his/her mind, but also with his/her heart (Parikh and Neubauer, 1993). Empirically, motivation of staff was found to be the direct predictor of enhanced staff satisfaction in Thai retail stores (Kantabutra, 2008b). Thai store managers who acted as a role model, built employee self-confidence, created challenges for employees, and rewarded staff who acted consistently with their visions are directly predictive of enhanced staff satisfaction. In the present study, we adopt measured items that have been endorsed in the previous study (Kantabutra, 2008b) as reliable measures for motivation in Thailand.

Despite the importance of motivation in the literature, several researchers have eliminated motivation from their factor analyses or have combined motivation with idealized influence to improve the construct validity in their studies (Densten, 2002). As a consequence, further clarification of the contribution of motivation in the visionary leadership process is required here. Motivation in this study is operationally defined as the extent to which a supervisor is perceived by his/her subordinates to (1) act as a role model for subordinates, (2) build subordinates' self confidence, (3) create challenges for subordinates, and (4) reward subordinates who act consistently with his/her vision.

\section{Organizational Alignment}

Visionary leaders need to align organizational systems, including the recruiting system, reporting lines, incentives, teamwork versus individual focus, and job design, to support their visions (e.g. Priem and Rosenstein, 2000; Kantabutra, 2010b). Not only do visionary leaders align people and supporting systems to suit their visions (Kouzes and Posner, 1987; Locke et al., 1991; Nanus, 1992), but good visions also align people in organizations (Parikh and Neubauer, 1993). Such an alignment frees energies that up to then may have been consumed by internal friction and political infighting. The process of developing vision and strategies, aligning relevant people behind those strategies, and empowering individuals to turn the vision into reality, despite obstacles, is regarded as leadership (Kotter, 1999).

More critically, Kantabutra (2010b) has asserted that visionary leaders who do not align organizational systems with their visions negatively affect follower satisfaction, given that an initially positive effect from vision on staff satisfaction in a Thai retail store setting turned negative when taking into account other visionary leadership variables of motivation of staff, vision communication and staff emotional factor. Kantabutra (2010b) explained that since his study did not take into account the effect from the organisational alignment variable, motivated and visionguided staff members might have been frustrated while trying to achieve their store manager visions with store systems not yet supportive. This indicates a need to re-examine the criticality of organizational alignment in the Thai setting. 
Organizational alignment in the present study is operationally defined as the extent to which a leader is perceived by subordinates to (1) adjust employee roles and responsibilities to suit his/her vision; (2) set up a new employee selection policy according to the vision; (3) realign organizational processes to suit the vision; (4) adjust employee promotion criteria to support the vision; and (5) adjust employee performance evaluation criteria to support the vision.

\section{LEADERSHIP OUTCOME: EMPLOYEE SATISFACTION}

A visionary leader depends on employees who accept and help to execute the vision (e.g. Daft, 2005; Kantabutra, 2009). Visionary leadership is effective only if employees become committed to the vision promoted by the leader (Avery, 2004; Kantabutra, 2009). Therefore, the vision must meet follower desires. Research has also shown that effective visionary leaders are in tune with their follower needs (Gilmore and Shea, 1997). Clearly, where managers serve as immediate supervisors, the type and quality of leadership they provide can influence employee satisfaction, either positively or negatively (Kantabutra, 2010b; Oliver, 1998). Endorsing this view, applied studies have shown that a supervisor's leadership style is related in some complex ways to the job satisfaction of subordinates (Bass, 1985). Indeed, employees were more satisfied under visionary leadership than under other leadership styles (Bass, 1985).

Empirically, staff who used their store manager's vision to guide their daily operations reported enhanced staff satisfaction in Australian retail stores (Kantabutra and Avery, 2006). In this context, the more staff members believed in their store manager's vision and did whatever it took to achieve the vision, the higher their own satisfaction. In Thai retail stores, motivation of staff was found to be the direct predictor of enhanced staff satisfaction, while empowerment of staff and vision communication were indirect predictors of improved staff satisfaction (Kantabutra, 2008b). In terms of relationship between employee satisfaction and performance outcomes, Zhu, Chew and Spangler (2005) suggest that visionary leadership leads to high levels of organizational outcomes such as commitment, trust, and motivation.

Without suggesting that it exhaustively explains overall organizational performance, employee satisfaction is adopted in the present study as the leadership outcome. Employee satisfaction is operationally defined here as the extent to which a subordinate is satisfied with (1) dollar remuneration, (2) fringe benefits, (3) autonomy (job-related independence, initiative, and freedom), (4) task requirements (job activities that must be done), (5) organizational policies, (6) interaction (formal/informal, social and professional contact at work), (7) professional status, (8) quality of supervision, (9) colleagues, (10) recognition of success, and (11) career advancement (Slavitt, Stamps, Piedmont and Hasse, 1986).

\section{STRUCTURAL MODEL}

Figure 1 below depicts a structural model tested in the present study. The model indicates relationships between vision communication, motivation and empowerment of employees and employee satisfaction derived from the literature on vision, business strategy, leadership, and business performance. Given that (a) external factors such as industry-wide government intervention and changes in the business environment could possibly intervene in the vision-performance process (Westley and Mintzberg, 1989), and (b) Thomas (1988) argues that other factors such as type of industry could similarly influence leadership effects within a given organization, these factors are largely controlled in the present study by conducting it in one organization, at a specific point in time, and under a specific set of similar organizational circumstances. In doing so, external effects evenly affect the sample. 


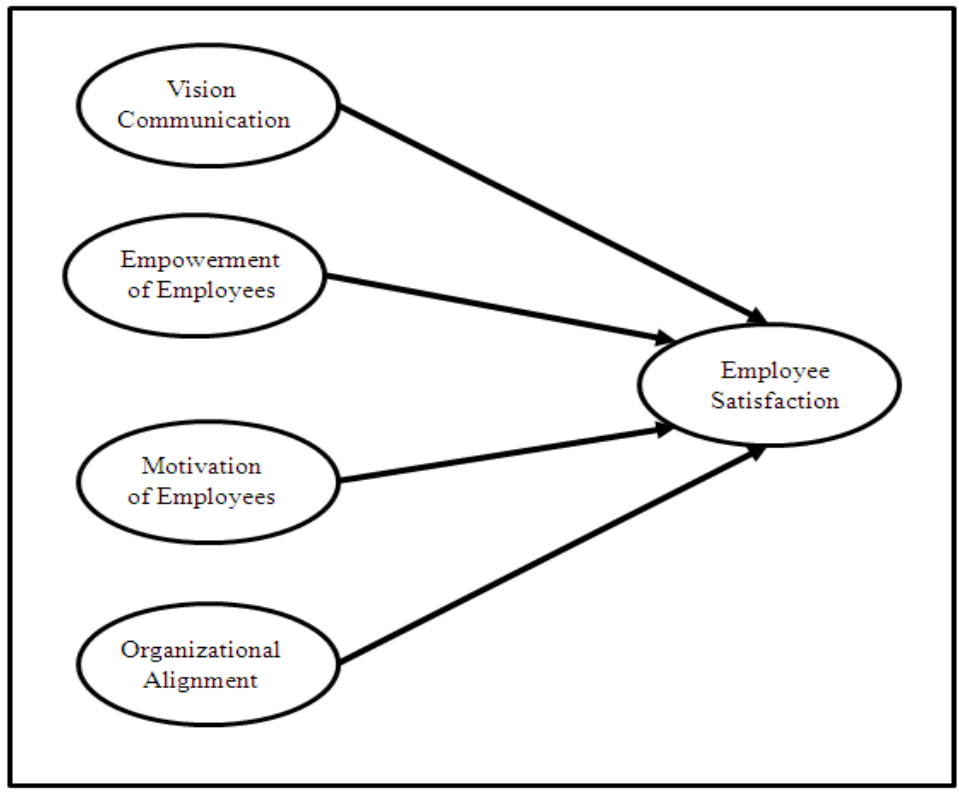

Figure 1. Structural Model

Based on the structural model, the following directional hypotheses are advanced, since the literature continues pointing out the positive impact of vision-based leadership on performance outcomes.

$\mathbf{H}_{\mathbf{1}}$ : Vision Communication is directly predictive of enhanced Employee Satisfaction.

$\mathbf{H}_{2}$ : $\quad$ Motivation of Employees is directly predictive of enhanced Employee Satisfaction.

$\mathbf{H}_{3}$ : $\quad$ Empowerment of Employees is directly predictive of enhanced Employee Satisfaction.

$\mathbf{H}_{4}$ : Organizational Alignment is directly predictive of enhanced Employee Satisfaction.

\section{METHODS}

The sample was drawn from the Bangkok branch of Southeast Asia's Leading Luxury Hotel Group in Thailand. The branch employs a total of 187 employees. The sample is convenient, comprising 178 employees who were willing to participate in the survey, representing $95 \%$ of the entire population. The majority (31) of the respondents have been with the branch for over 10 years, indicating a sufficient length of time to observe leadership styles of their immediate supervisors.

The questionnaire was initially developed in English, and was translated into Thai for respondents by a bilingual professional translator. The Thai questionnaire was translated back to English by a different bilingual professional translator to ensure sufficient face validity. A nine-point ordinal scale underlay all questionnaire items measuring the domains in Figure 1. The questionnaire collected data on vision communication, motivation, empowerment, organizational alignment and satisfaction. Each employee respondent was asked to respond to items about his/her direct supervisor's perceived behaviors on vision communication (com1, com2, com3), motivation (mo1, mo2, mo3, mo4) and empowerment (em1, em2, em3) of employees, and organizational alignment (align1, align2, align3, align4, align5). Employees also responded to the eleven items (sat1, sat2, sat3, sat4, sat5, sat6, sat7, sat8, sat9, sat10, sat11) of job satisfaction (Slavitt et al., 1986).

Combining scores of sub-variables to form each of the other independent measurement domain constructs is considered justified, because they are adjusted according to results of a factor analysis (see Table 1). 
Rotated Component Matrix ${ }^{a}$

\begin{tabular}{|l|c|c|c|c|}
\hline & \multicolumn{4}{|c|}{ Component } \\
\cline { 2 - 5 } & 1 & 2 & 3 & 4 \\
\hline com2 & & & .892 & \\
mo2 & & & .903 & \\
em3 & & & & .805 \\
align1 & .801 & & & \\
align2 & .804 & & & \\
align3 & .778 & & & \\
align4 & .846 & & & \\
align5 & .943 & & & \\
sat9 & & .896 & & \\
sat10 & & .954 & & \\
sat11 & & .927 & & \\
\hline
\end{tabular}

Extraction Method: Principal Component Analysis. Rotation Method: Varimax with Kaiser Normalization.

a. Rotation converged in 5 iterations.

Table 1. Results of Factor Analysis

All factor loadings loaded at 0.7 or higher, but those of Vision Communication item 1 (spoken), Motivation items 1, 3-6, Empowerment items 1 and 2, and Employee Satisfaction items 1-8, all of which are dropped. The Motivation construct has one item left, which is " build subordinates' self confidence", while the Empowerment construct has one item left which is "encouraging staff to make decisions regarding daily operations". These two items are combined together to form a new Motivation construct (PMot) because both items can be perceived as motivation of staff. All remaining items of other constructs are combined to form their relevant Vision Communication (PVCom), Organizational Alignment (POrgAli) and Employee Satisfaction (SSat) constructs.

After all of the adjustments and combinations, construct validity for all constructs is therefore sufficiently present. Cronbach's alphas are employed to confirm the reliability of Vision Communication, Motivation of Employees, Organizational Alignment and Employee Satisfaction variables (see Table 2). All scales display Cronbach's alpha values exceeding or close to 0.7 , an acceptable reliability value (Nunnally, 1978).

\begin{tabular}{|c|l|r|}
\hline No. & \multicolumn{1}{|c|}{ Variable Names } & Alpha Values \\
\hline 1 & Vision Communication & 0.76 \\
\hline 2 & Motivation of Staff & 0.68 \\
\hline 3 & Organizational Alignment & 0.89 \\
\hline 4 & Staff Satisfaction & 0.91 \\
\hline
\end{tabular}

Table 2. Cronbach's Alphas

\section{RESULTS}

Employee respondents perceived that their immediate supervisors communicated the vision, motivated them and aligned organizational systems to suit the vision to varying extents. Similarly, they also felt satisfied with their jobs at the hotel to varying extents. Please see Table 3. 
Descriptive Statistics

\begin{tabular}{|l|r|r|r|c|r|}
\hline & \multicolumn{1}{|c|}{$\mathrm{N}$} & Minimum & Maximum & Mean & Std. Deviation \\
\hline PVCom & 178 & 2.00 & 18.00 & 11.1011 & 4.37906 \\
PMot & 178 & 4.00 & 18.00 & 15.0337 & 2.53094 \\
POrgAli & 178 & 14.00 & 45.00 & 32.5056 & 11.28433 \\
SSat & 178 & 9.00 & 27.00 & 21.1348 & 4.15434 \\
Valid N (listwise) & 178 & & & & \\
\hline
\end{tabular}

Table 3. Descriptive Statistics

A correlation analysis (Table 4) reveals that there is a positive correlation between Motivation of Employees and Employee Satisfaction in the present study. There is also a negative correlation between Organizational Alignment and Motivation of Employees.

\begin{tabular}{|ll|r|r|r|r|}
\hline \multicolumn{6}{|c|}{ Correlations } \\
\hline PVCom & \multicolumn{1}{|c|}{ PVCom } & \multicolumn{1}{c|}{ PMot } & \multicolumn{1}{c|}{ POrgAli } & \multicolumn{1}{c|}{ SSat } \\
& Pearson Correlation & 1 & -.002 & .033 & .112 \\
& Sig. (1-tailed) & & .490 & .333 & .068 \\
& $\mathrm{~N}$ & 178 & 178 & 178 & 178 \\
\hline PMot & Pearson Correlation & -.002 & 1 & $-.135^{*}$ & $.142^{*}$ \\
& Sig. (1-tailed) & .490 & & .036 & .029 \\
& $\mathrm{~N}$ & 178 & 178 & 178 & 178 \\
\hline POrgAli & Pearson Correlation & .033 & $-.135^{*}$ & 1 & .056 \\
& Sig. (1-tailed) & .333 & .036 & & .229 \\
& $\mathrm{~N}$ & 178 & 178 & 178 & 178 \\
\hline SSat & Pearson Correlation & .112 & $.142^{*}$ & .056 & 1 \\
& Sig. (1-tailed) & .068 & .029 & .229 & \\
& $\mathrm{~N}$ & 178 & 178 & 178 & 178 \\
\hline
\end{tabular}

*. Correlation is significant at the 0.05 level (1-tailed).

Table 4. Correlation Analysis Result among Vision Communication, Motivation of Employees and Organizational Alignment, and Employee Satisfaction

A regression analysis (Table 5) indicates that Motivation of Employees is the direct predictor of enhanced Employee Satisfaction in the present study, while Organizational Alignment and Vision Communication do not have any direct or indirect effect on Employee Satisfaction.

\begin{tabular}{|c|c|c|c|c|c|c|}
\hline \multicolumn{7}{|c|}{ Coefficients ${ }^{a}$} \\
\hline \multirow[b]{2}{*}{ Mods } & & \multicolumn{2}{|c|}{ Unstandardized Coefficients } & $\begin{array}{l}\text { Standardized } \\
\text { Coefficients }\end{array}$ & \multirow[b]{2}{*}{$t$} & \multirow[b]{2}{*}{ Sig. } \\
\hline & & B & Std. Error & Beta & & \\
\hline \multirow[t]{4}{*}{1} & (Constant) & 15.341 & 2.311 & & 6.639 & .000 \\
\hline & PVCom & .104 & .071 & .110 & 1.477 & .141 \\
\hline & PMot & .250 & .123 & .153 & 2.033 & .044 \\
\hline & POrgAi & .027 & .028 & .073 & .971 & .333 \\
\hline
\end{tabular}

a. Dependent Variable: SSat

Table 5. Regression Analysis Result between Vision Communication, Motivation of Employees and Organizational Alignment, and Employee Satisfaction 
All hypotheses are rejected, except $\mathrm{H}_{2}$ because there is a significant direct relationship between Motivation of Employees and Employee Satisfaction. A direct significant relationship is defined as a relationship that still remains significant at $\mathrm{p}<0.05$ when all other observed variables are taken into account in the regression analysis.

\section{DISCUSSION}

Vision communication is said by numerous scholars to be a key to become successful in implementing vision in an organization (e.g. Avery, 2004; Bass, 1985; Bennis and Nanus, 1985; Conger and Kanungo, 1987). It is viewed as a tool to promote changes and broaden support among employees. Vision communication in this study, however, is not consistent with the broader literature because it has no significant relationship with employee satisfaction in the hotel branch. This can possibly be explained that visions here might not be effective. Scholars (Rafferty and Griffin, 2004, Senge, 1990) suggest that vision can be strong or weak, negative or positive. In the present study, such quality of supervisor vision is not taken into account. Therefore, communicating a "bad" vision might have been ineffective. Moreover, vision content can also explain the insignificant relationship here. Vision content is seen as critical for a vision and its communication to be effective (Kantabutra and Avery, 2007). In general, vision content can focus on products, services, markets, organizations or even ideals (Westley and Mintzberg, 1989). In a retail setting, Kantabutra and Avery (2007) found that content about customer and employee satisfaction was positively correlated to customer and employee satisfaction outcomes. In the financial services industry, three commonalities among vision content were identified. All of the statements were goal oriented, indicated how the firms intended to conduct their businesses, and addressed the type of environment that would be provided for employee (O'Brien and Meadows, 2003). Future research should incorporate vision content to determine effectiveness of vision communication.

Another missing element from the present study is vision attributes. According to Kantabutra's (2009) theory, an effective vision is characterized by seven attributes of brevity, charity, abstractness, stability, future orientation, challenge and desirability/ability to inspire. A vision needs to contain these attributes so that leaders can effectively communicate the vision in an organization. Unfortunately, the present study does not take these attributes into consideration. Although supervisors are perceived to communicate their visions by their employees, their visions might not be effective, rendering no effect on employee satisfaction. Future research might consider including the seven attributes for further testing.

Factors stemming from leaders themselves are also important (Kantabutra, 2006). Visionary leaders are passionate about their visions, which is said to affect follower outcomes and overall business performance (Kotter, 1996). In a more recent study in Australian retail stores, leader passion was a direct predictor of improved employee satisfaction (Kantabutra and Vimolratana, 2009). Future studies may consider taking into account leader passion to determine leadership effectiveness.

Organizational alignment has a negative relationship with motivation of employees in the present study. Organizational alignment is defined here as the extent to which a supervisor is perceived by employees to adjust roles and responsibilities to suit the vision, to set up a new employee selection policy according to the vision, to realign organizational processes to suit the vision, to adjust promotion criteria to support the vision, and to adjust performance evaluation criteria to support the vision, while motivation of employees is defined as the extent to which a supervisor is perceived by his/her employees to encourage them to make more decisions regarding daily operations and build their self confidence. Clearly, this finding makes much sense. The more a supervisor attempts to change organizational systems, which in turn appears to negatively affect the work of his/her employees (i.e. new processes mean burden), the less the employees will perceive that the supervisor encourages them to make more decisions regarding their daily operations and help them to be more confident in their work. Future research might want to explore this hypothesized relationship further.

Additionally, follower vision sharing might have played a role here (Kantabutra, 2006). A shared vision between leaders and followers has long been widely regarded as a key to superior performance (Avery, 2004; Reardon, 1991; Sashkin, 1985; Senge, 1990). People need to find meaning in their work (Nanus, 1992). A desirable vision can provide the meaning, gain affective commitment from followers, and widen a leader's support base by reflecting the needs and aspiration of many stakeholders, transcending individual differences, and drawing 
stakeholders into a community of concerns about the future of the organization (Nanus, 1992). Follower emotional commitment to their leader's vision is indeed considered important for a vision to take effect, because when followers are committed, they tend to be willing to work toward the vision (Collins and Porras, 1994; Lipton, 1996). Without an effective vision communication to get employees to share a vision in the present study, the hotel employees might have perceived newly aligned work processes as extra work, possibly bringing about the negative relationship between motivation of employees and organizational alignment. This requires further studies.

Motivation of employees is the only direct predictor of enhanced employee satisfaction in the present study, endorsed by the broader literature (e.g. Awamleh and Gardner, 1999; Kantabutra, 2008b). This finding should not be a surprise since employee motivation is negatively correlated to organizational alignment here and we are looking at a close relationship between a supervisor and his/her employees. When demotivated employees are motivated, they should be directly satisfied. Since many measured items for empowerment and motivation in the present study are dropped, given their insufficient factor loadings, future research might consider testing the items again in different organizational settings.

\section{MANAGERIAL IMPLICATIONS}

In order to directly improve employee satisfaction, supervisors at all levels of the hotel need to encourage their employees to make more decisions regarding daily operations and to build their self confidence. They should also be very careful about crafting a vision for their own use since it appears that the supervisors here do communicate their visions, but their vision communication renders no significant effect on their employee satisfaction. In doing so, they may consider crafting vision content and attributes. In the hotel industry, leaders may focus their vision content on excellent services to emphasize the importance of delivering quality services among the hotel employees. Moreover, they may consider adopting Kantabutra's (2009) theory of effective vision in developing a vision statement for their own use. Based on the theory, an effective vision must be brief, clear, stable, future oriented, inspiring, challenging and abstract.

Hotel supervisors have to adjust employee roles and responsibilities to suit the vision, to set up a new employee selection policy according to the vision, to realign organizational processes to suit the vision, to adjust employee promotion criteria to support the vision, and to adjust employee performance evaluation criteria to support the vision. In order for the newly align work process to become "positive", the hotel supervisors should, as their employees going through implementing the newly aligned systems, motivate their employees through various methods such as the use of formal authority, role modelling, building self-confidence, creating challenge through goal-setting, delegating, and rewarding and punishing.

To gain emotional commitment from employees to prevent possible negative effects from the visionary leadership process, the hotel supervisors should communicate an "effective" vision and be passionate about their vision by being supportive to their vision and acting consistently with their.

\section{ACKNOWLEDGEMENTS}

The author would like to acknowledge data collection efforts of Piyaporn Parnichparinchai, Patchareeporn Kulasingh, and Oracha Chaiprasansawad.

\section{AUTHOR INFORMATION}

Sooksan Kantabutra teaches in the College of Management at Mahidol University, Bangkok, Thailand. E-mail: cmsooksan@mahidol.ac.th

\section{REFERENCES}

1. Aarons, G. A. (2006) Transformational and transactional leadership: Association with attitudes toward evidence-based practice. Psychiatric Services, 57: 8 pp1162-1169. 
2. Alban-Metcalfe, R. J. And Alimo-Metcalfe, B. (2000) An analysis of the convergent and discriminant validity of the transformational leadership questionnaire, International Journal of Selection \& Assessment. 8: 3 pp158-75.

3. Alimo-Metcalfe, B. And Alban-Metcalfe, J. (2006) More (good) leaders for the public sector, International Journal of Public Sector Management. 19: 4 pp293-315.

4. Avery, G. C. (2005) Leadership for Sustainable Futures: Achieving Success in a Competitive World, Cheltenham, UK: Edward Elgar.

5. $\quad$ Avery, G.C. (2004) Understanding Leadership, London: Sage.

6. Avolio, B. J. (1999) Full Leadership Development: Building the Vital Forces in Organizations, Thousand Oaks, CA: Sage.

7. Awamleh, R. And Gardner, W. (1999) Perceptions of leader charisma and effectiveness: The effects of vision content, delivery, and organizational performance, Leadership Quarterly. 10: 3 pp345-373.

8. Bandura, A. (1986) Social Foundations of Thought and Action: A Social Cognitive Theory, Englewood Cliffs, NJ: Prentice-Hall.

9. Bass, B. M. (1990) Bass and Stogdills Handbook of Leadership: Theory, Research, and Managerial Applications, New York: Free Press.

10. Bass, B. M. (1985) Leadership and Performance Beyond Expectations, New York: Free Press.

11. Baum, J. R. And Locke, E. A. (2004) The relationship of entrepreneurial traits, skill, and motivation to subsequent venture growth, Journal of Applied Psychology. 89 pp587-598.

12. Baum, J. R., Locke, E. A. And Kirkpatrick, S. A. (1998) A longitudinal study of the relation of vision and vision communication to venture growth in entrepreneurial firms, Journal of Applied Psychology. 83 pp4354.

13. Bennis, W. G., And Nanus, B. (1985) Leaders: The Strategies for Taking Charge, New York: Harper and Row.

14. Boehnke, K., Bontis, N., Distefano, J. J., And Distefano, A. C. (2003) Transformational leadership: An examination of cross-national differences and similarities, Leadership \& Organisational Development. 24: $1 \mathrm{pp} 5-15$.

15. Brodbeck, F. C., Frese, M., Akerblom, S., Audia, G., Bakacsi, G., And Bendova, H. (2000) Cultural variation of leadership prototypes across 22 European countries. Journal of Occupational and Organizational Psychology, 73: 1 pp1-29.

16. Carson, C. M. And King Jr., J. E. (2005) Leaving leadership: Solving leadership problems through empowerment, Management Decision. 43 pp1049-1053.

17. Collins, J. C. And Porras, J. I. (1994) Built to Last: Successful Habits of Visionary Companies, London: Century.

18. Conger, J. A. (1991) Inspiring others: the language of leadership, Academy of Management Executive. 5: 1 pp31-45.

19. Conger, J. A. And Kanungo, R. N. (1987) Toward a behavioral theory of charismatic leadership in organizational settings, Academy of Management Review. 12 pp637-647.

20. Cowley, M. And Domb, E. (1997) Beyond Strategic Vision, Boston: Butterworth-Heinemann.

21. Daft, R. L. (2005) The Leadership Experience, Mason, OH: Thomson South-Western.

22. Daft, R. L. And Lengel, R. H. (1998) Fusion Leadership: Unlocking the Subtle Forces that Change People and Organizations, San Francisco: Berrett-Koehler.

23. Dastmalchian, A., Javidan, M., And Alam, K. (2001). Effective leadership and culture in Iran: An empirical study. Applied Psychology: An International Review (Special Issue: Leadership and culture in the Middle East: Norms, practices, and effective leadership attributes in Iran, Kuwait, Turkey, and Qatar), 50: 4 pp532-558.

24. Den Hartog, House, R., Hanges, P., And Ruiz-Quintanilla, S. (1999) Culture specific and cross-culturally generalizable implicit leadership theories: Are attributes of charismatic/transformational leadership universally endorsed? Leadership Quarterly, 10: 2 pp219-256.

25. Densten, I. L. (2002) Clarifying the relationship between inspirational motivation and extra effort, The Leadership and Organizational Development Journal. 22: 1 pp40-44.

26. Dorfman, P. W. And Howell, J. P. (1997) Leadership in Western and Asian countries: Commonalities and differences in effective leadership processes across cultures, Leadership Quarterly. 8: 3 pp233-275. 
27. Doz, Y. L. And Prahalad, C. K. (1987) 'A process model of strategic redirection in large complex firms: The case of Multinational Corporations' in A. Pettigrew (ed) The Management of Strategic Change, Oxford, UK: Basil Blackwell.

28. Forrester, R. (2000) Empowerment: Rejuvenating a potent idea, Academy of Management Executive. $14: 3$ pp67-80.

29. Gilmore, T. N. And Shea, G. P. (1997) Organizational learning and the leadership skill of time travel, Journal of Management Development. 16: 4 pp302-311.

30. Gupta, V., Surie, G., Javidan, M. And Chhokar, J. (2002) Southern Asia cluster: where the old meets the new?, Journal of World Business. 37: 1 pp16-27.

31. Hamel, G. And Prahalad, C. K. (1989) Strategic intent, Harvard Business Review. 67 (May-June) pp63-76.

32. Hardy, C. And Leibia-O'Sullivan, S. (1998) The power behind empowerment: implications for research and practice, Human Relations. 51 pp451-83.

33. Hetland, H. And Sandal, G. M. (2003) Transformational leadership in Norway: outcomes and personality correlates, European Journal of Work and Organizational Psychology. 12: 2 pp147-171.

34. Hofstede, G. (1983) Dimensions of National Cultures in Fifty Countries and Three Regions in J. Deregowski, S. Dziurawiec, and R. C. Annis (eds) Expiscations in Cross-Cultural Psychology. Lisse, Netherlands: Swets and Zeitlinger.

35. Humphreys, J. (2004) The vision thing, MIT Sloan Management Review. Spring, p96.

36. Hunt, J. G. (1991) Leadership: A New Synthesis, Newbury Park, CA: Sage.

37. Javidan, M. And Carl, D. E. (2004) East meets West: A cross-cultural comparison of charismatic leadership among Canadian and Iranian executives, Journal of Management Studies. 41: 4 pp665-91.

38. Jayakody, J. A .S. K. (2008) Charismatic leadership in Sri Lankan business organizations, Journal of Management Development. 27: 5 pp480-498.

39. Jick, T. (2001) Vision is 10\%, implementation is the rest, Business Strategy Review. 12: 4 pp36-38.

40. Kabasakal, H. And Dastmalchian, A. (2001) Introduction to the Special Issue on Leadership and Culture in the Middle East. Applied Psychology An International Review (Special Issue: Leadership and culture in the Middle East: Norms, practices, and effective leadership attributes in Iran, Kuwait, Turkey, and Qatar), 50: 4 pp479-488.

41. Kantabutra, S. (2005) Improving public school performance through vision-based leadership, Asia Pacific Education Review. 6:2 pp 124-136.

42. Kantabutra, S. (2008a) What do we know about vision?, Journal of Applied Business Research. $24: 2$ pp127-38.

43. Kantabutra, S. (2008b) Vision effects in Thai retail stores: practical implications, International Journal of Retail And Distribution Management. 36: 4 pp323-42.

44. Kantabutra, S. (2009) Toward a behavioral theory of vision in organizational settings, Leadership and Organization Development Journal. 30: 4 pp319-337.

45. Kantabutra, S. (2010b). Negative vision effect in Thai retail stores. Singapore Management Review: Asia Pacific Journal of Management Theory and Practice. 32:1 pp1-27.

46. Kantabutra, S., And Avery, G. C. (2002) Proposed model for investigating relationships between vision components and business unit performance, Journal of the Australian and New Zealand Academy of Management. 8: 2 pp22-39.

47. Kantabutra, S. And Avery, G. C. (2006) Follower effects in the visionary leadership process, Journal of Business and Economics Research. 4: 5 pp57-65.

48. Kantabutra, S. (2006). Leader and follower factors in customer and employee satisfaction: It takes two to tango. Journal of Applied Business Research, 22:4, pp33-45.

49. Kantabutra, S. And Avery, G. C. (2007) Vision effects in customer And staff satisfaction: An empirical investigation, Leadership and Organization Development Journal. 28: 3 pp209-229.

50. Kantabutra, S. And Vimolratana, P. (2009) Vision-based leadership: Relationships and consequences in Thai and Australian retail stores, Asia-Pacific Journal of Business Administration. 1: 2 pp165-188.

51. Kantabutra, S. (2011). Examining store manager effects in consumer and staff satisfaction: Evidence from Thailand, Journal of Retailing and Consumer Services, 18: 1 pp.46-57.

52. Kantabutra, S. (2010a) What do we know about vision? in G.R. Hickman (ed) Leading Organizations: Perspectives for a New Era. Thousand Oaks, California: Sage.

53. Kotter, J. P. (1988) The Leadership Factor, New York: Free Press. 
54. Kotter, J. P. (1996). Leading Change. Boston, MA: Harvard Business School Press.

55. Kotter, J. P. (1990) A Force for Change: How Leadership Differs from Management, New York: Free Press.

56. Kotter, J. P. (2001) What leaders really do, Harvard Business Review. 79: 11 pp85-96.

57. Lipton, M. (1996). Demystifying the development of an organizational vision. Sloan Management Review, 37: 4, pp83-91.

58. Lucey, J., Bateman, N. And Hines, P. (2005) Why major lean transitions have not been sustained, Management Services. 49: 2 pp9-13.

59. Maciariello, J. A. (2006) 'Peter F. Drucker on executive leadership and effectiveness' in F. Hesselbein and M. Goldsmith The Leader of the Future, San Francisco: Jossey-Bass.

60. McShane, S. L. And Von Glinow, M. A. (2000) Organizational Behavior, New York: McGraw-Hill.

61. Mukherjee, K. (2004) Effects of leadership styles on employees' satisfaction and perceived effectiveness. South Asian Journal of Management, 11: 1 pp7-19.

62. Nanus, B. (1992) Visionary Leadership: Creating A Compelling Sense of Direction for Your Organization, San Francisco: Jossey-Bass.

63. Nunnally, J. L. (1978) Psychometric Theory, New York: McGraw-Hill.

64. Oliver, J. (1998) Invest in people and improve profitability and productivity, Management Today. March pp90-91.

65. Parikh, J. And Neubauer, F. (1993) 'Corporate Visioning' in D. E. Hussey (ed) International Review of Strategic Management, Chichester: Wiley.

66. Pasa, S. F., Kabasakal, H. E., And Bodur, M. (2001) Society, organisations, and leadership in Turkey. Applied Psychology: An International Review (Special Issue: Leadership and culture in the Middle East: Norms, practices, and effective leadership attributes in Iran, Kuwait, Turkey, and Qatar), 50: 4 pp559-589.

67. Popper, M. And Druyan, N. (2001) Cultural prototypes? Or leaders' behaviors? a study on workers' perceptions of leadership in an electronic industry, Journal of Managerial Psychology. 16: 7 pp549-58.

68. Popper, M. And Sleman, K. (2001) Intercultural differences and leadership perceptions of Jewish and Druze school principals, Journal of Educational Administration. 39: 3 pp221-232.

69. Priem, R.L. And Rosenstein, J. (2000) Is organisation theory obvious to practitioners? A test of one established theory, Organisation Science. 11:5 pp.509-24.

70. Rafferty, A. E., \& Griffin, M. G. (2004). Dimensions of transformational leadership: Conceptual and empirical extensions. Leadership Quarterly, 15,pp.329-354.

71. Reardon, K. K. (1991) Persuasion in Practice. Newbury Park, CA: Sage.

72. Robbins, S. R., And Duncan, R. B. (1987) The formulation and implementation of strategic vision: a tool for change, Seven Strategic Management Society Conference, Boston, MA, October pp14-17.

73. Sashkin, M. (1985) Creating a corporate excellence culture: identifying levers and how to use them, Emprender. 21: 145 pp36-39.

74. Sashkin, M. (1988) 'The Visionary leader' in J. A. Conger and R. N. Kanungo (eds) Charismatic Leadership: The Elusive Factor in Organizational Effectiveness, San Francisco: Jossey-Bass.

75. Senge, P. M. (1990). The Fifth Discipline: The Art \& Practice of the Learning Organization. New York: Currency Doubleday.

76. Singh, R.K., Krishnan, V.R. (2002) Impact of impression management and value congruence on attributed charisma. NMMS Management Review, 14: 1 pp86-94.

77. Slavitt, D., Stamps, P., Piedmont, E. And Hasse, A. (1986) Index of Work Satisfaction, Michigan: University of Michigan Press.

78. Spreitzer, G. M. (1995) Psychological empowerment in the workplace: Dimensions, measurement and validation, Academy of Management Journal. 38 pp1442-1465.

79. Tarabishy, A., Solomon, G., Fernald Jr., L. W. And Sashkin, M. (2005) The entrepreneurial leaders impacton the organizations performance in dynamic markets, Journal of Private Equity. 8: 4 pp20-29.

80. Thomas, A. (1988) Does leadership make a difference to organizational performance?, Administrative Science Quarterly. 33: 3 pp388-400.

81. Westley, F. And Mintzberg, H. (1989) Visionary leadership and strategic management, Strategic Management Journal. 10, Summer pp17-32. 
82. Zhu, W., Chew, I. K. H. And Spangler, W.D. (2005) CEO transformational leadership \& organizational outcomes: The mediating role of human-capital-enhancing human resource management, The Leadership Quarterly. 16: 1 pp39-52. 